\section{Ground vibration due to blasting in dam and hydropower projects}

Rudarsko-geološko-naftni zbornik

(The Mining-Geology-Petroleum Engineering Bulletin) UDC: 622.2

DOI: 10.17794/rgn.2020.3.6

Preliminary communication

\author{
Hojjat Hosseinzadeh Gharehgheshlagh'; Aref Alipour ${ }^{2}$ \\ ${ }^{1 *}$ Mining Engineering Department, Faculty of Environment, Urmia University of Technology (UUT), Box: 57155-419, \\ Postal code: 5716693188, Band road, Urmia, West Azerbaijan, Iran. ORCID (https://orcid.org/0000-0002-7763-9596). \\ ${ }^{2}$ Mining Engineering Department, Faculty of Environment, Urmia University of Technology (UUT), Box: 57155-419, \\ Postal code: 5716693188, Band road, Urmia, West Azerbaijan, Iran. ORCID (https://orcid.org/0000-0003-0946-3477).
}

\begin{abstract}
In this study, the safe charge per delay ( $\mathrm{kg}$ ) of explosives and Peak Particle Velocity (PPV, mm/s) are recorded for 140 blast events at various distances which relates to the dam and hydropower projects of Karoun III, Masjed - Soleiman, and Siah - Bisheh in Iran. Parameters of Scaled Distance (SD) are estimated carefully. For the prediction of PPV, empirical equations are used. The correlation coefficients resulting from these predictors in diverse sites, are different because of varying conditions in the geomechanical and blasting parameters at each site. Therefore, considering several initial blasts and analysing their results, a suitable relationship has been selected for each case study.
\end{abstract}

\title{
Keywords:
}

peak particle velocity (PPV); blasting; ground vibration; empirical equations.

\section{Introduction}

The drilling and blasting process is one of the most important and most common methods used for the excavation of underground spaces, such as tunnels, caverns, powerhouses, etc. Undoubtedly, blast-induced ground vibration is an undesirable result in these kinds of projects. Additionally, environmental constraints will be restricted more and more on mining activities (Yilmaz et al., 2016). Hence, a good measurement of ground vibration caused by blasting significantly affects the control of environmental problems (Li et al., 2010; Kahriman, 2004). Although the need for standards has been observed, there are no efficient standards of blast vibration for underground structures and research is to be conducted in this area (Jiang and Zhou, 2012; Shuyu and Zhemin, 2014).

One of the quantitative methods for estimating vibration is the evaluation of PPV $(\mathrm{mm} / \mathrm{s})$ which is induced by blasting in the surrounding rocks and is a measure that defines and is used for ground vibrations. For this purpose, many theoretical and empirical formulations have been proposed (Duvall and Fogelson, 1962; Attewell, 1964 \& 2013; Ambraseys, 1968; Nicholls et al., 1971; Indian Standard Institute, 1973; Langefors and Kihlström, 1978; Ghosh and Daemen, 1983; Roy, 1993; Adhikari et al., 1994; Kumar et al., 2014a \& 2014b; Kumar et. al., 2016; Jayasinghe et al., 2019). Empirical

Corresponding author: Hojjat Hosseinzadeh Gharehgheshlagh h.hoseynzade@uut.ac.ir \&h.hoseynzade@yahoo.com models have two basic parameters; they are the distance from the location of blasting and the maximum load per delay. Considering the diversity of geomechanical parameters and the pattern of blasting, the compatibility of these equations changes in different places.

The permissible limits of PPV for underground openings have been reported by various investigators. In one of the related studies, a threshold value of PPV for the safety of underground openings has been determined based on the RMR of the roof, pillar and floor of underground works separately. The threshold values of PPV for the safety of the roof, pillars and floor have been determined to be 100, 40 and $20(\mathrm{~mm} / \mathrm{s})$ respectively (Singh et al., 2015). $P P V=100(\mathrm{~mm} / \mathrm{s})$ did not lead to the destruction of the underground mining of coal having RMR of 50 (Singh, 2002). Kidybiński (1986) demonstrates that when the PPV lies in the 50-200 ( $\mathrm{mm} / \mathrm{s})$ range, this may cause small to large roof falls in underground coal mining workings. No damage in underground coal mine workings at $58 \mathrm{~mm} / \mathrm{s}$ is observed. PPV of $175 \mathrm{~mm} / \mathrm{s}$ did not cause any damage to underground openings when $\mathrm{RMR}=85$ was encountered (Tunstall, 1997). In the present study, an effort has been made to estimate PPV with an empirical model in three different dam and hydropower projects.

\section{Geographical position of case studies}

For this study, three dams and hydropowers in Iran were investigated and their specifications are as below: 
1) Karoun III: The dam and hydropower project of Karoun III is in the province of Khoozestan, Iran. This dam, which is a concrete double arch type, has a 468.28 $\mathrm{m}$ crest length, 205 and $185 \mathrm{~m}$ height (from foundation and river bed, respectively) and 29.5 and $5.5 \mathrm{~m}$ width (from foundation and crest, respectively). This dam, which has a reservoir capacity of $3 \mathrm{bcm}$, can produce $2000 \mathrm{MW}$ of electrical power. Underground excavations of this dam consist of powerhouses, access tunnels and shafts are located in the vicinity of the dam body (IWPC, 2000).

2) Masjed - Soleiman: The dam and hydropower of Masjed - Soleiman is near the city of Masjed - Soleiman in Khoozestan province, Iran. This dam, which is a rockfill dam type, has a $497 \mathrm{~m}$ crest length, 177 and $164 \mathrm{~m}$ height (from the foundation and river bed, respectively) and 780 and $15 \mathrm{~m}$ wide (from the base and crest, respectively). This dam, which has a reservoir capacity of 2.69

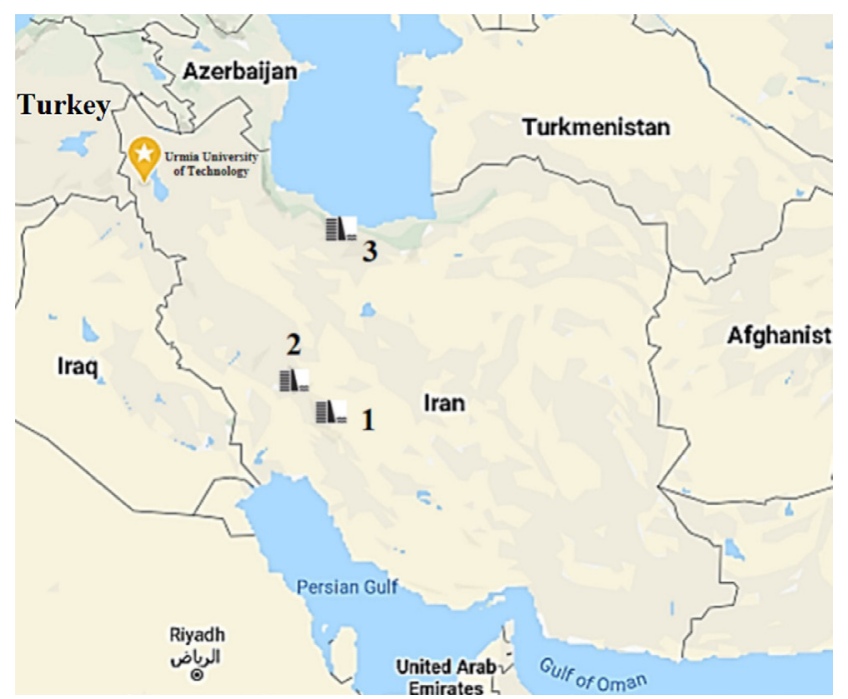

Figure 1: Positions of investigated Dam and Hydropower projects in Iran map (1: Karoun III, 2: Masjed - Soleiman, 3: Siah - Bishe) bcm, can produce $2000 \mathrm{MW}$ of electrical power. This project consists of an earth fill dam on the river of Karoun and structures of its sideways consist of the spillway, diversion tunnels, grouting tunnels, draining tunnels and one underground powerhouse and its structures (IWPC, 1998).

3) Siah - Bishe: The Siah - Bishe pumped storage dam and power plant project is near the country of the Siah - Bishe in Mazandaran province, Iran. This project consists of two dams in the upstream and downstream part of the Chaloos River. Both the upper and lower reservoirs are created by concrete-face rock-filled dams. The upper dam is $82.5 \mathrm{~m}$ tall and $436 \mathrm{~m}$ long and is $12 \mathrm{~m}$ wide at its crest and $280 \mathrm{~m}$ wide at its base. Its reservoir has a storage capacity of approximately $4.34 \mathrm{mcm}$. The lower reservoir dam is $102 \mathrm{~m}$ tall and $332 \mathrm{~m}$ long and is $12 \mathrm{~m}$ wide at its crest and $360 \mathrm{~m}$ wide at its base. Its reservoir has a storage capacity of approximately $6.87 \mathrm{mcm}$. The installed electrical capacity of the Siah - Bishe dam is 260 MW. Its sideways structures consist of the spillway, diversion tunnels, grouting tunnels, draining tunnels, and an underground powerhouse (IWPC, 2001).

Figure 1 shows the positions of these projects in Iran.

\section{Petrology of case studies}

The zone of the dam and powerhouse of Karoun III is composed of limestone, marly limestone, marlstone, and shale (IWPC, 2000). In the Masjed - Soleiman site, the cavern and underground spaces are located in the Bakhtiari and Aghajari, the rocks of this formation are the varieties of conglomerate, sandstone, siltstone, and mudstone (IWPC, 1998). The rocks of the Siah - Bishe site are the synthesis of sedimentary and igneous rocks. Sedimentary rocks are generally quartz sandstone, siltstone, Intrusive, Limestone and marl (IWPC, 2001). Table 1 gives a summary of the characteristics of rocks in these three sites.

Table 1. Geomechanical characteristics of rocks in the sites.

\begin{tabular}{|l|l|l|l|l|l|}
\hline Site & Rock type & Density, t/m & Yong modulus, GPa & UCS, MPa & RMR \\
\hline \multirow{5}{*}{ 1) Karoun III } & Limestone & 2.50 & 20.00 & 98.00 & 75.00 \\
\cline { 2 - 6 } & Marly limestone & 2.40 & 20.00 & 98.00 & 65.00 \\
\cline { 2 - 6 } & Marlstone & 2.30 & 17.00 & 50.00 & 55.00 \\
\cline { 2 - 6 } & Shale & 2.30 & 17.00 & 50.00 & 50.00 \\
\hline \multirow{5}{*}{ 2) Masjed - Soleiman } & Conglomerate & 2.70 & 50.00 & $25.00-65.00$ & 83.00 \\
\cline { 2 - 6 } & Sandstone & 2.75 & 65.00 & $20.00-30.00$ & 75.00 \\
\cline { 2 - 6 } & Siltstone & 2.55 & 32.00 & $7.00-15.00$ & 58.00 \\
\cline { 2 - 6 } & Claystone & 2.50 & 25.00 & 15.00 & 44.00 \\
\hline & Siltstone & 2.63 & 2.14 & 27.00 & 36.00 \\
\cline { 2 - 6 } & Quartz sandstone & 2.81 & $30.00-48.00$ & $60.00-120.00$ & 60.00 \\
\cline { 2 - 6 } & $\begin{array}{l}\text { Limestone and } \\
\text { marl }\end{array}$ & 2.40 & 3.50 & 40.00 & 40.00 \\
\cline { 2 - 6 } & Intrusive & 2.80 & 15.00 & $90.00-100.00$ & 70.00 \\
\cline { 2 - 6 } & Shale & 2.78 & $3.00-7.00$ & $14.00-20.00$ & 40.00 \\
\hline
\end{tabular}


Table 2. Drilling and blasting outlines.

\begin{tabular}{|l|l|l|l|l|}
\hline Parameter & Case study & Drifts & Tunnels & Bench blasting \\
\hline \multirow{4}{*}{ Hole diameter (mm) } & 1) Karoun III & No Drifts & 45.00 & 32.00 \\
\cline { 2 - 5 } & 2) Masjed - Soleiman & 64.00 & 51.00 & 32.00 \\
\cline { 2 - 5 } & 3) Siah - Bishe & 64.00 & 51.00 & 32.00 \\
\hline \multirow{5}{*}{ Hole length (m) } & 1) Karoun III & No Drifts & $2.00-4.00$ & $1.20-2.00$ \\
\cline { 2 - 5 } & 2) Masjed - Soleiman & 3.00 & $2.00-4.00$ & $1.20-2.00$ \\
\cline { 2 - 5 } & 3) Siah - Bishe & 3.60 & $2.00-4.00$ & $1.60-2.00$ \\
\hline \multirow{2}{*}{$\begin{array}{c}\text { Explosive (Dynamite) } \\
\text { cartridge diameter }(\mathrm{mm})\end{array}$} & 1) Karoun III & No Drifts & $22.00 \& 30.00$ & 22.00 \\
\cline { 2 - 5 } & 2) Masjed - Soleiman & 30.00 & 30.00 & 22.00 \\
\cline { 2 - 5 } & 3) Siah - Bishe & 30.00 & 30.00 & 22.00 \\
\hline Powder factor $\left(\mathrm{kg} / \mathrm{m}^{3}\right)$ & 1) Karoun III & No Drifts & $1.10-2.00$ & 2.00 \\
\cline { 2 - 5 } & 2) Masjed - Soleiman & 0.25 & $1.00-1.80$ & 2.00 \\
\cline { 2 - 4 } & 3) Siah - Bishe & 0.25 & $0.80-1.60$ & 2.00 \\
\hline
\end{tabular}

Table 3. Ground vibration measurements results.

\begin{tabular}{|c|c|c|c|c|}
\hline $\begin{array}{l}\text { Site of blast } \\
\text { operation }\end{array}$ & $\begin{array}{l}\text { No. } \\
\text { shot }\end{array}$ & $\begin{array}{l}\text { R: Distance } \\
\text { (m) }\end{array}$ & $\begin{array}{l}\text { Q: Maximum } \\
\text { charge per } \\
\text { delay }(\mathrm{kg})\end{array}$ & $\begin{array}{l}\text { PPV } \\
(\mathrm{mm} / \mathrm{s})\end{array}$ \\
\hline \multirow[t]{5}{*}{ Karoun III } & 1 & 130.00 & 30.50 & 0.70 \\
\hline & 10 & 90.91 & 41.00 & 3.70 \\
\hline & 20 & 102.00 & 35.00 & 1.30 \\
\hline & 30 & 163.00 & 54.00 & 0.90 \\
\hline & 33 & 167.00 & 52.75 & 7.20 \\
\hline \multirow{5}{*}{$\begin{array}{l}\text { Masjed } \\
\text { - Soleiman }\end{array}$} & 1 & 145.00 & 7.70 & 0.65 \\
\hline & 10 & 110.76 & 24.00 & 11.30 \\
\hline & 20 & 74.00 & 18.00 & 6.40 \\
\hline & 30 & 80.00 & 24.00 & 12.20 \\
\hline & 38 & 83.00 & 24.00 & 11.30 \\
\hline \multirow[t]{7}{*}{ Siah-Bishe } & 1 & 18.00 & 7.00 & 13.70 \\
\hline & 10 & 50.00 & 7.00 & 4.35 \\
\hline & 20 & 75.50 & 20.00 & 8.72 \\
\hline & 30 & 52.20 & 8.00 & 7.80 \\
\hline & 40 & 126.00 & 20.00 & 2.89 \\
\hline & 50 & 103.00 & 12.00 & 3.96 \\
\hline & 55 & 98.60 & 19.20 & 4.63 \\
\hline
\end{tabular}

\section{Blasting operation in the case studies}

The nature of enormous powerhouse projects causes blasting operations to be carried out in the vicinity of instrumentation, turbines and generators, and other underground spaces; therefore, it is essential to use controlled blasting, and all information such as utilized charge per delay and the distance of the monitoring stations from the site of blasting is monitored. The used explosive was Akhgar dynamites made by the Parchine Company. Two dynamites with diameters of 22 and 30 $\mathrm{mm}$ were used. Production specifications of Akhgar dynamite are as follows: these explosive materials are a mixture of Nitroglycerin, Nitrocellulose, Ammonium nitrate, and other additives. Power specifications, effective energy relative to ANFO, cartridge density and ve- locity of detonation of Akhgar dynamite are 1.25-1.4 (g/ $\left.\mathrm{cm}^{3}\right)$, and 4000-5000 (m/s), respectively. Table 2 consists of characteristics of underground drilling and blasting of these case studies. It is necessary to mention, due to constraints and differences in the geological and geomechanical specifications in each study, there may be variations in the blast pattern (including blast hole diameter and length).

\section{Monitoring of blast-induced ground vibration data}

To achieve an appropriate pattern of drilling and blasting in the excavation of underground spaces, simultaneously with the excavation of other spaces, the quantity of vibration and other data was monitored. In each cycle of blasting, data regarding the maximum utilized charge per delay, distance of geophone from the site of blasting, PPV, vibration frequency, etc., was collected for analysis. To study the effects of blast vibrations in the Karoun III excavations, data measurement operations were performed with a seismograph model UVS500 made by Nitro Nobel company, and, in Masjed-Soleiman, data measurement operations were carried out with ' UVS1500'. Nitro Nobel geophone's can measure particles' velocity in three main directions and the resultant amplitude. The geophones used in these two sites were not able to record the frequency of vibration. Data measurement operations in Siah - Bishe were performed with a BlastMate III model seismograph made by the Geonor company. BlastMate III can measure PPV and vibration frequency amplitude in three main directions. The measurement results of ground vibration investigations that were carried out on the case studies, including PPV, total charge, charge per delay, and distance are presented in Table 3.

Ground vibration is influenced by a number of parameters such as the physicomechanical properties of a rock-mass, explosive characteristics and blast design 
(Khandelwal and Singh, 2006). Until now, there have not been efficient investigations on the relevancy of the geo-mechanic and blast parameters of ground vibration. A limited number of these investigations have modeled the effect of rock characteristics, explosive characteristics and blast design. The limited research in this field includes the use of artificial intelligence methods in references (Khandelwal and Singh, 2006; 2009; Yuan et al., 2014; Singh and Singh, 2005). The use of blackbox models such as artificial neural networks in practical applications in the construction project and mining sites is impossible and clearly formulated models have been required. Observed frequencies are less than $100 \mathrm{~Hz}$ for mining blasts and not over $250 \mathrm{~Hz}$ even for construction blasts (Berta, 1994; Adhikari and Singh, 1989). In this study, for example, the frequency ranges of measured PPV values in Siah - Bishe varied from 4 to $108 \mathrm{~Hz}$. Based on the data available on this site, analyses have been performed to link the prevailing frequencies to the geomechanical characteristics, which did not yield quantitatively interpretable results.

\section{Analysis of monitored data with empirical equations}

To reduce the influence of earth vibration and to protect the structures, researchers have proposed different equations, with regard to various criteria, for the prediction of blasting vibration based on experimental data. For instance, the most important empirical equations can be seen in Table 3. In these three equations, the emphasis is on the charge per delay and distance from the blasting site; and geomechanical and blasting parameters are less significant. Also, there are some constants in the equations which demonstrate the effect of geomechanical and blasting parameters. The results of previous investigations show that $B$ and $K$ constants are affected by geomechanical parameters and the type of explosive (Hossaini and Sen, 2004). In all of the equations in Table 4; PPV and Q are peak particle velocity $(\mathrm{mm} / \mathrm{s})$ and the maximum charge for each delay $(\mathrm{kg}), \mathrm{R}$ is the distance from charge point (m) and K, B and A are local constant coefficients that are calculated by a regression

Table 4. List of equations (all types used by researchers are versions of the following general forms).

\begin{tabular}{|l|l|l|}
\hline Name & $\begin{array}{l}\text { Peak Particle Velocity } \\
\text { equation }\end{array}$ & $\begin{array}{l}\text { SD } \\
\text { equation }\end{array}$ \\
\hline Attewell, 1964 & $\mathrm{PPV}=\mathrm{K} \mathrm{R}^{-\mathrm{A}} \mathrm{Q}^{\mathrm{B}}(1)$ & \\
\hline $\begin{array}{l}\mathrm{USBM} \\
\text { (Duvall \& } \\
\text { Fogelson), 1962 }\end{array}$ & $\mathrm{PPV}=\mathrm{K}\left(\mathrm{R} / \mathrm{Q}^{0.5}\right)^{-\mathrm{B}}(2)$ & $\mathrm{R} / \mathrm{Q}^{0.5}$ \\
\hline $\begin{array}{l}\text { Ambraseys } \\
- \text { Hendron, 1968 }\end{array}$ & $\mathrm{PPV}=\mathrm{K}\left(\mathrm{R} /\left[\mathrm{Q}^{2 / 3}\right]\right)^{-\mathrm{B}}(3)$ & $\mathrm{R} /\left[\mathrm{Q}^{2 / 3}\right]$ \\
\hline $\begin{array}{l}\text { Langefors } \\
- \text { Kihlstrom, 1978 }\end{array}$ & $\mathrm{PPV}=\mathrm{K}\left[\left(\mathrm{Q} /\left[\mathrm{R}^{3 / 2}\right]\right)^{0.5}\right]^{\mathrm{B}}(4)$ & $\left(\mathrm{Q} /\left[\mathrm{R}^{3 / 2}\right]\right)^{0.5}$ \\
\hline
\end{tabular}

method. SD parameter is defined as the ratio of the distance from the charge point and a form of the square root of charge mass (related to an empirical model).

Actually, empirical equations that estimate vibration intensity are functions of the SD parameter; and also this parameter is a function of distance from blasting site (R) and maximum charge per delay (Q). Table 4 shows the SD parameter for each empirical equation of Duvall and Fogelson (1962), Ambraseys - Hendron (1968), and Langefors - Kihlstrom (1978). In these three models, $R$ is scaled according to the $\mathrm{Q}$ value, but, in the Attewell model $\mathrm{R}$ and $\mathrm{Q}$ independently participate in the equation, therefore, the SD parameter is not defined in the Attewell model.

For statistical analysis, for all case studies and all models (except the Attewell model), firstly, the $\mathrm{R}_{\mathrm{i}}$ and $\mathrm{Q}_{\mathrm{i}}$ values were used for calculation of the corresponding $\mathrm{SD}_{i}$ values. Then, by using the obtained $\mathrm{SD}_{i}$ and $\mathrm{PPV}$ values, a data series was created for each case study model conditions. As a result, nine data series were created for three case studies and three models. Next, for each data series, a chart with $\mathrm{X}$-axis values SD and Yaxis values PPV was created. Finally, the $\mathrm{K}$ and $\mathrm{B}$ values were obtained by fitting a power function on this chart. The results of statistical analysis in each case study are listed in Table 5. The correlation coefficients $\left(\mathrm{r}^{2}\right)$ vary between 0.45 and 0.84 . According to Table 5, the Langefors - Kihlstrom equation for Karoun III has the maximum correlation coefficient rather than other case studies and equations.

Table 5. Results of statistical analysis for fitting empirical criteria to data in different sites.

\begin{tabular}{|l|l|l|l|l|}
\hline Equation & project & $\mathbf{B}$ & $\mathbf{K}$ & $\mathbf{r}^{2}$ \\
\hline \multirow{2}{*}{$\begin{array}{l}\text { USBM } \\
\text { Duvall \& } \\
\text { Fogelson), } 1962\end{array}$} & Karoun III & 2.445 & 1825 & 0.81 \\
\cline { 2 - 5 } & $\begin{array}{l}\text { Masjed } \\
- \text { Soleiman }\end{array}$ & 1.288 & 299 & 0.62 \\
\cline { 2 - 5 } & Siah - Bishe & 1.185 & 175 & 0.62 \\
\hline \multirow{2}{*}{$\begin{array}{l}\text { Ambraseys } \\
- \text { Hendron, 1968 }\end{array}$} & Karoun III & 2.41 & 7671 & 0.77 \\
\cline { 2 - 5 } & $\begin{array}{l}\text { Masjed } \\
- \text { Soleiman }\end{array}$ & 1.9 & 397 & 0.53 \\
\cline { 2 - 5 } & Siah - Bishe & 1.185 & 303 & 0.67 \\
\hline \multirow{4}{*}{$\begin{array}{l}\text { Langefors }- \text { Kihlstrom, 1978 } \\
\text { Karoun III }\end{array}$} & $\begin{array}{l}\text { Masjed } \\
- \text { Soleiman }\end{array}$ & 1.23 & 400.86 & 0.84 \\
\cline { 2 - 5 } & Siah - Bishe & 1.62 & 188.6 & 0.70 \\
\hline
\end{tabular}

Considering the results of Table 5, it is clear that the Langefors - Kihlstrom equation (Equation 4) is suitable for the site of Masjed - Soleiman. Furthermore, in the site of Siah - Bishe, Ambraseys - Hendron equation (Equation 3) has the highest correlation value compared with the other equations, and the Langefors - Kihlstrom equation has less performance in this case. Empirical equations show different characteristics in various projects. It is possible that one equation is suitable for a 
particular case study; however, maybe it has low accuracy for another case study. Generally, the ability of each equation should be evaluated for a particular site and the equation that has the best correlation must be chosen.

The relationship between PPV and SD used by the empirical equation of the United States Bureau of Mine (Duvall \& Fogelson, 1962) is shown in Figure 2 for all three case studies; furthermore, this relationship proposed by Ambraseys - Hendron and Langefors - Kihlstrom is demonstrated in Figure 3 and 4 . According to the Ambraseys - Hendron and empirical equation of USBM, Figures 2 and $\mathbf{3}$, the quantity of PPV for an SD in the site of Masjed - Soleiman is higher than the PPV in Siah - Bishe. A di-

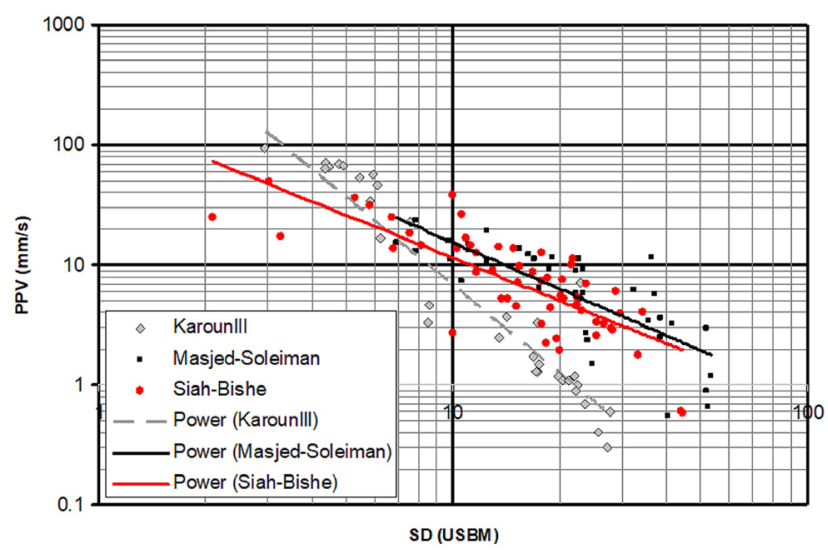

Figure 2: PPV versus SD parameter of 3 different sites by using the USBM (Duvall - Fogelson) model

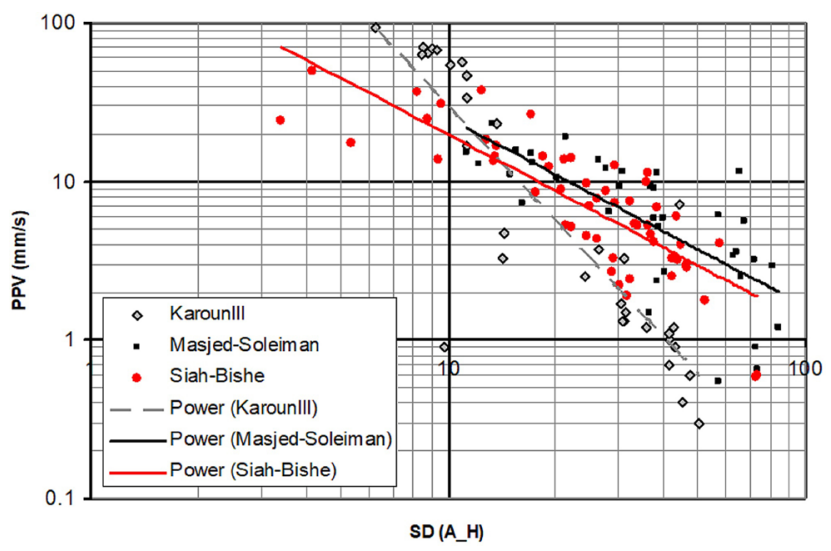

Figure 3: PPV versus SD parameter of 3 different sites by using the Ambraseys - Hendron model

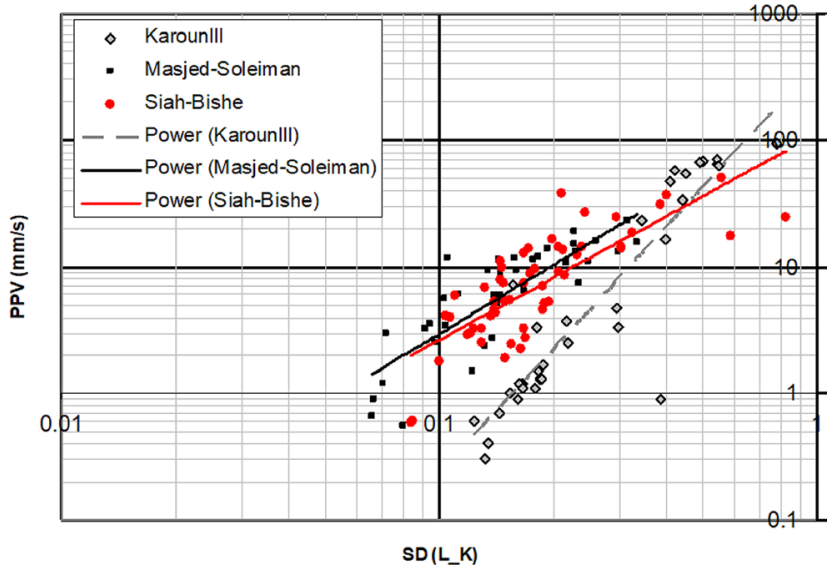

Figure 4: PPV versus SD parameter of 3 different sites by using the Langefors - Kihlstrom

verse tendency can be seen in the site of Karoun III in contrast to the sites of Siah - Bishe and Masjed - Soleiman; as for the lower scale distances and the higher scale distances, higher quantities of PPVs and lower quantity of PPVs have been observed, respectively.

According to the different thresholds of damage instructions in underground spaces, see Figures 2, 3, and 4 and Table 5, the monitored PPVs were safe and conservative. However, the blast vibration detector was installed in sensitive areas with a relatively high distance from the blasting site and certainly, in the neighbouring area, the vibration intensity had been higher.

So far, no certain standard has been given to determining the reliable limit of PPV for underground structures, and the studies on this subject have limited. For example, Adhikari et al. (2003) developed a stratification system for weak and medium rocks using PPV values. If the rocks of the Masjed - Soleiman and Karoun III sites are classified as moderate rocks and the rocks of the Siah - Bishe site are classified as weak rocks, then the performance of executive engineers is acceptable and with respect to the onset threshold of damage in Table 6, the maximum charges of each delay are reasonable.

\section{Conclusion}

No standard method exists for vibration controlling in caverns and underground spaces and most of the availa-

Table 6. Nature of damage with respect to PPV (Adhikari et al., 2003).

\begin{tabular}{|l|l|l|}
\hline \multirow{2}{*}{ Nature of damage } & $\mathbf{P P V}, \mathbf{m m} / \mathbf{s}$ \\
\cline { 2 - 3 } & $\begin{array}{l}\text { For medium rock at Kalyadi } \\
\text { Copper Mines \& HGML }\end{array}$ & $\begin{array}{l}\text { For weak rock } \\
\text { Ramagiri Gold Mine \& BGML }\end{array}$ \\
\hline No damage & Less than 153 & Less than 52 \\
\hline Opening \& widening of joints & $153-217$ & $52-195$ \\
\hline Dislodging of loose pieces & $217-367$ & $195-297$ \\
\hline Induced cracking & $367-604$ & $297-557$ \\
\hline Excessive damage & Greater than 604 & Greater than 557 \\
\hline
\end{tabular}


ble standards are related to the surface structures. In other words, no certain standard has been given to define a reliable limit of PPV for underground structures. Therefore, in this article, only the studies on this subject that have limited numbers are referred. For example, the information of the two case studies containing weak and medium quality rocks given in Table 6 is only for the evaluation of our results since there are no other suitable criteria and scales.

In the studied cases, the distances of the surface structures from the blasting site were high and they were not affected by blasting. The maximum charge in each delay in the Karoun III, Masjed - Soleiman and Siah - Bishe sites are 90,34 and $22.5 \mathrm{~kg}$, respectively.

The number of experiments performed in each case study is different and ranges from 40 to 60 . The values given in Table 3 show some of these randomly selected experiments (No. shot). The PPV values of all experiments are given in Figures 2, 3 and 4. Considering the results of all three case studies given in Figures 2, 3, and 4, the maximum values of measured PPV at the monitoring locations were less than $100 \mathrm{~mm} / \mathrm{s}$. For these studies, even at the highest PPV value recorded, no damage to the rock mass was observed and therefore these are consistent with the details given in Table 6. PPV monitored in the site of Karoun III, demonstrates that the charge in each delay was rather high; but in the other sites the charges were not high and the monitored PPVs are at low levels.

In most cases, the choice of the delay charge is mostly affected by local conditions. For instance, the executions of the extension phase in the powerhouse of Masjed Soleiman in the vicinity of dam body, and the powerhouse of phase one in Masjed - Soleiman for a weak and complex condition of geology are the reasons to choose a small amount of delay charge.

With regard to the acceptable blasting vibration, using the Langefors - Kihlstrom equation for the site of Karoun III and Masjed - Soleiman, the Ambraseys - Hendron equation for the site of Siah - Bishe are suitable and these equations are suggested for the safe design of blasting.

Tables 1 and $\mathbf{2}$ represent the geological structures and blasting pattern parameters of all three case studies. The effect of these differences is presented clearly in Figures 2, 3 and $\mathbf{4}$ for each of the three empirical models. On the other hand, these differences are also seen in the values of the correlation coefficients listed in Table 5. Drastic variations of geology and effective geomechanical parameters caused a low value for the correlation coefficient. Despite these apparent differences, no quantitative and distinct relationship was found between the content of Tables 1 and $\mathbf{2}$ and the three empirical models, for each case study.

\section{References}

Adhikari, G.A., Rajan, B., Venkatesh, H.S., Thresraj, A.I. (1994): Blast damage assessment for underground struc- ture. Proceedings of the National Symposium on emerging mining and ground control technologies. Varanasi, India. 247-55.

Adhikari, G.R., Balachander, R., Theresraj, A.I., Gupta, R.N. (2003): Damage Control Blast Design for Excavation of Desilting Chambers at Nathpa Jhakri Hydroelectric Project. Journal of Rock Mechanics and Tunnelling Technology (JRMTT), Vol 9 (NO.2), 105 - 114.

Adhikari, GR., Singh, RB. (1989): Structural response to ground vibration from blasting in opencast coal mines. Journal of Mines, Metals \& Fuels, 37 (4), 135 - 138.

Ambraseys, NR., Hendron, AJ. (1968). Dynamic behaviour of rock masses. In: Stagg K, Wiley J, editors. Rock mechanics in engineering practice. London: Wiley, 203e7 p.

Attewell, P. B. (1964): Recording and Interpretation of Shock Effects in Rocks. Mining and Minerals Engineering, $21-28$.

Berta, G. (1994): Blasting-induced vibration in tunnelling. Tunnelling and Underground Space Technology, 9 (2), 175 $-187$.

Duvall, W. I., Fogelson, D. E. (1962): Review of criteria for estimating damage to residences from blasting vibrations. US Department of the Interior, Bureau of Mines, Washington, D.C., 19 p.

Ghosh, A., Daemen, J. J. (1983): A simple new blast vibration predictor (based on wave propagation laws). $24^{\text {th }}$ US Symposium on Rock Mechanics (USRMS), Texas.

Hossaini, S., Sen, G. (2004): Effect of explosive type on particle velocity criteria in ground vibration. Journal of Explosives Engineering, 21 (4), 34 - 36.

Indian Standard Institute. (1973): Criteria for safety and design of structures subjected to underground blast, ISI Bull, IS -6922 .

IWPC. (1998): Underground Works Construction Report Engineering Geology Godar-E-Lendar (Masjed - Soleiman) H.E.P.P. Retrieved from.

IWPC. (2000): Underground Works Construction Report Engineering Geology Karoun III H.E.P.P. Retrieved from.

IWPC. (2001): Siah Bishe PSP Project Engineering Report 2.

Jayasinghe, B., Zhao, Z., Goh, A., Chee, T., Zhou, H.B., Gui, Y. (2019): Attenuation of rock blasting induced ground vibration in rock-soil interface. Journal of Rock Mechanics and Geotechnical Engineering, 11, 770 - 778.

Jiang, N., Zhou, C. (2012): Blasting vibration safety criterion for a tunnel liner structure. Tunnelling and Underground Space Technology, 32, $52-57$.

Kahriman, A. (2004): Analysis of parameters of ground vibration produced from bench blasting at a limestone quarry. Soil Dynamics and Earthquake Engineering, 24(11), 887 - 892. https://doi.org/10.1016/j.soildyn.2004.06.018.

Khandelwal, M., Singh, T. N. (2006): Prediction of blast induced ground vibrations and frequency in opencast mine: A neural network approach. Journal of Sound and Vibration, 289 (4), 711 - 725. doi: http://dx.doi.org/10.1016/j. jsv.2005.02.044.

Khandelwal, M., Singh, T. N. (2009): Prediction of blast-induced ground vibration using artificial neural network. International Journal of Rock Mechanics and Mining Sci- 
ences, 46 (7), 1214 - 1222. doi: https://doi.org/10.1016/j. ijrmms.2009.03.004.

Kidybiński, A. (1986): Design criteria for roadway supports to resist dynamic loads. International Journal of Mining and Geological Engineering, 4(2), 91 - 109. https://doi. org/10.1007/BF01560669.

Kumar, R., Choudhury, D., Bhargava, K. (2014a): Prediction of blast-induced vibration parameters for soil sites. International Journal of Geomechanics, 14(3). https://doi. org/10.1061/(ASCE)GM.1943-5622.0000355.

Kumar, R., Choudhury, D., Bhargava, K. (2014b): Response of shallow foundation in rocks subjected to underground blast loading using FLAC3D. Disaster Advances, 7(2), 64 - 71.

Kumar, R., Choudhury, D., Bhargava, K. (2016): Determination of blast-induced ground vibration equations for rocks using mechanical and geological properties. Journal of Rock Mechanics and Geotechnical Engineering, 8, 341 - 349.

Langefors, U., Kihlström, B. (1978): The modern technique of rock blasting. Wiley (3rd edition), Michigan, $438 \mathrm{p}$.

Li, X., Chen, J., Li, Y., Dai, Y. (2010): Study of blasting seismic effects of underground chamber group in Xiluodu hydropower station. Chinese Journal of Rock Mechanics and Engineering, 29(3), 493 - 501.

Nicholls, H.R., Charles, F.J., Duvall, WI. (1971): Blasting vibrations and their effects on structures. U.S. Department of the Interior, Bureau of Mines, Washington, D.C., 105 p.

Roy, P. (1993): Putting ground vibration predictions into practice. Colliery Guardian, 241(2), $63-67$.
Shuyu, F., Zhemin, Z. (2014): Sixty years of engineering blasting in China: Review and prospect. Engineering, 6, 001 (in Chinese - with English abstract)

Singh, P. K. (2002): Blast vibration damage to underground coal mines from adjacent open-pit blasting. International Journal of Rock Mechanics and Mining Sciences, 39(8), $959-973$.

Singh, P. K., Roy, M. P., Paswan, R. K., Dubey, R. K., Drebenstedt, C. (2015): Blast vibration effects in an underground mine caused by open-pit mining. International Journal of Rock Mechanics and Mining Sciences, 80, 79 - 88. https:// doi.org/10.1016/j.ijrmms.2015.09.009.

Singh, TN., Singh, V. (2005): An intelligent approach to prediction and control ground vibration in mines. Geotechnical \& Geological Engineering, 23 (3), 249 - 262.

Tunstall, A. (1997): Damage to underground excavations from open-pit blasting. Transactions of the Institution of Mining and Metallurgy: Section A-Mining Industry, 106, A19 - A24.

Yilmaz, T., Karaman, K., Cihangir, F., Ercikdi, B., Kesimal, A. (2016): Effect of Tunnel Blasting Operation on the Surface Penstock Pipe. IOP Conference Series: Earth and Environmental Science, Prague.

Yuan, Q., Wu, L., Zuo, Q., Li, B. (2014): Peak particle velocity and principal frequency prediction based on RS-FNN comprehension method for blasting vibration. Electronic Journal of Geotechnical Engineering, 19, 10043-10056. 


\section{SAŽETAK}

\section{Vibracije tla uslijed miniranja u branama i hidroelektranama}

U ovoj studiji razmatrano je sigurno punjenje eksploziva $(\mathrm{kg})$ s odgodom i vršna brzina čestica (VBZ, mm/s) na 140 miniranja na različitim udaljenostima u sklopu projekata brane i hidroelektrane Karoun III, Masjed - Soleiman i Siah Bisheh u Iranu. Parametri skalirane udaljenosti pažljivo su procijenjeni. Za predviđanje VBZ-a korištene su empirijske jednadžbe. Koeficijenti korelacije koji su proizišli iz tih procjena različiti su za različite lokacije zbog različitih geomehaničkih uvjeta i parametara miniranja na svakoj lokaciji. Stoga je, uzevši u obzir nekoliko početnih miniranja i analizirajući njihove rezultate, odabrana odgovarajuća veza za svaki pojedini slučaj studije.

\section{Ključne riječi:}

vršna brzina čestica (VBZ), miniranje, vibracije tla, empirijske jednadžbe

\section{Authors contribution}

Hojjat Hosseinzadeh Gharehgheshlagh, Assistant Professor of Mining Engineering, collaborated in the literature review, data collection and analysis procedure for this manuscript. Aref Alipour, Assistant Professor of Mining Engineering, collaborated on the data collection, analysis procedure, writing and managing the whole process of this manuscript.

\begin{tabular}{|l|l|}
\hline \multicolumn{2}{|l|}{ List of acronyms and symbols } \\
\hline A & model (empirical equations) constant \\
\hline ANFO & Ammonium Nitrate/Fuel Oil \\
\hline B & model (empirical equations) constant \\
\hline bcm & billion cubic meters \\
\hline BGML & Bharat Gold Mines Limited \\
\hline $\mathrm{g} / \mathrm{cm}^{3}$ & gram per cubic centimeter \\
\hline $\mathrm{GPa}$ & Giga Pascal \\
\hline $\mathrm{HGML}$ & Hutti Gold Mines Company Limited \\
\hline $\mathrm{Hz}$ & hertz (cycles per second) \\
\hline $\mathrm{i}$ & corresponded data for each condition \\
\hline $\mathrm{K}$ & model (empirical equations) constant \\
\hline $\mathrm{kg}$ & kilogram \\
\hline $\mathrm{kg} / \mathrm{m}^{3}$ & kilogram per cubic meter \\
\hline $\mathrm{m}$ & meter \\
\hline $\mathrm{m} / \mathrm{s}$ & meter per second \\
\hline $\mathrm{mcm}$ & million cubic meters \\
\hline $\mathrm{mm}$ & millimeter \\
\hline $\mathrm{mm} / \mathrm{s}$ & millimeter per second \\
\hline $\mathrm{Mpa}$ & Mega Pascal \\
\hline $\mathrm{MW}$ & Mega Watt \\
\hline $\mathrm{PPV}$ & Peak Particle Velocity (mm/s) \\
\hline $\mathrm{Q}$ & maximum charge for each delay (kg) \\
\hline $\mathrm{R}$ & distance from charge point, $(\mathrm{m})$ \\
\hline $\mathrm{r}^{2}$ & correlation coefficient \\
\hline $\mathrm{RMR}$ & Rock Mass Rating \\
\hline $\mathrm{SD}$ & Scaled Distance \\
\hline $\mathrm{UCS}$ & Uniaxial Compressive Strength \\
\hline $\mathrm{USBM}$ & United States Bureau Of Mines \\
\hline
\end{tabular}

